\author{
2021, Volume 8, ID 519 \\ DOI: $10.15342 / \mathrm{ijms} .2021 .519$
}

\title{
REVIEW
}

\section{The Role of Sugars in the Caries Process}

\author{
Monique Adidémè Ezin, Houda El Khmmal, Hakima Chhoul \\ Department of Pedodontics-Prevention, Faculty of Dentistry, Rabat, Morocco
}

\begin{abstract}
The carious disease is a post-eruptive infectious pathology of the hard tissues of the tooth. It is the most common dental disease, with a prevalence of 60 to $90 \%$ in school children worldwide. It is a significant public health issue. The caries process involves cariogenic bacteria (mutans streptococci - lactobacilli), which, by metabolizing carbohydrates, produce acids that lower the $\mathrm{pH}$ of the oral cavity below a critical threshold and thus cause demineralization of the enamel.

Indeed, the consumption of sugars and sweetened products is a known risk factor for caries induction. The most cariogenic sugars are the fast sugars, mainly sucrose, widely used in the food industry. In addition to the nature of the sugar, several other factors condition the appearance of caries disease, namely the quantity of sugar consumed, its consistency, the duration of its contact with the teeth, the time and frequency of its consumption. Among the pillars of caries prevention, the control of the frequency and timing of consumption is essential. If the eradication of free sugars remains challenging to apply, their consumption must be reduced.

This article aims first to discuss the link between the different types of sugars and the caries process and then present the current recommendations for the consumption of sugars to prevent caries disease.
\end{abstract}

KEYWORDS: Diet - Sugars - Carbohydrates - Bacterial Biofilm - Fermentation - Caries.

Correspondence: Monique Adidémè Ezin, Department of Pedodontics-Prevention, Faculty of Dentistry, Rabat, Morocco. Email: monicaezin@gmail.com

Copyright (C) 2021 Ezin MA et al. This is an open access article distributed under the Creative Commons Attribution 4.0 International, which permits unrestricted use, distribution, and reproduction in any medium, provided the original work is properly cited.

\section{INTRODUCTION}

Caries is a multifactorial infectious disease involving three factors: the ingestion of fermentable carbohydrates, the presence of cariogenic bacteria, and the host's defense capabilities, particularly against the acidity produced by these bacteria $[1,2,3]$. In addition to these three factors, there is a fourth one: the time factor, which expresses the duration of exposure of the dental organ to sugars (Figure 1) [29]. The reason why the consumption of sugary foods remains a significant risk factor in the development of caries disease.

\section{THE DIFFERENT TYPES OF SUGARS}

In everyday language, we call "sugars" products belonging to the carbohydrate family. Their primary role is to provide energy for the proper functioning of the body. We distinguish:

Natural sugars: these are the sugars naturally present in the food.

Simple sugars: formula of (C6H12O6), with a sweet taste, represented by glucose and fructose (present in fruits, vegetables, natural honey ... ) are monosaccharides (composed of a single molecule of glucose or galactose, absorbed as such by the cells), lactose (present in milk) and sucrose (table sugar from beet or cane) are disaccharides (combination of two monosaccharides, often glucosegalactose or glucose-fructose or glucose-glucose, must be decomposed by digestion before their absorption by the cells) These simple sugars are immediately put in direct contact with the dental tissues and are therefore very cariogenic.

Complex sugars:

non-sweet taste, such as starch, glycogen, fibers (present in vegetables, cereals, bread, pasta...) are polysaccharides (a combination of several monosaccharides). Their availability for the cells takes more time because they must first go through decomposition to give glucose, and they are therefore less cariogenic than simple sugars.

Added sugars: these are sugars that the manufacturer adds to products; often, the consumer is not aware of these sugars in the food. They are used to improve the texture, taste, etc... [17,18]

The only sugar content mentioned on the nutritional label of the packages is the mono and disaccharides. [2] 


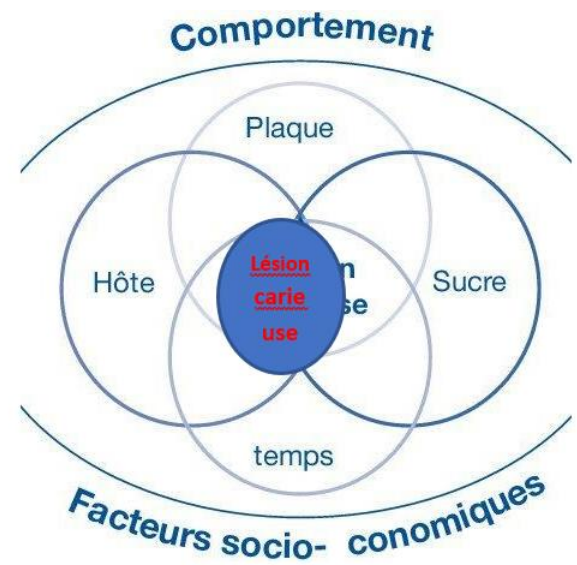

Figure 1: KEYES diagram modified by Newbrun reviewed by Reisne and Douglas. (1962)

\section{SWEETENING POWER}

The sweetness power (SP) represents the ability of a chemical compound to be perceived by an individual as sugar. It is determined to be a reference, usually, a sucrose solution, whose sweetness equals 1 . It is a number without a unit of measurement (Figure 2). Table 1 shows the sugar content of some commonly consumed foods. The reference for measurement is white sugar cubes of size 4 $(=5.95 \mathrm{~g})$ and size $3(=7.9 \mathrm{~g})$. (See Table 1) [30].

Table 2 lists some sugars and sweeteners with their PS, their capacity to induce acidification of the bacterial biofilm, and their cariogenicity as a function of contact time. The SP influences the $\mathrm{pH}$ but will not necessarily cause cariogenecity.

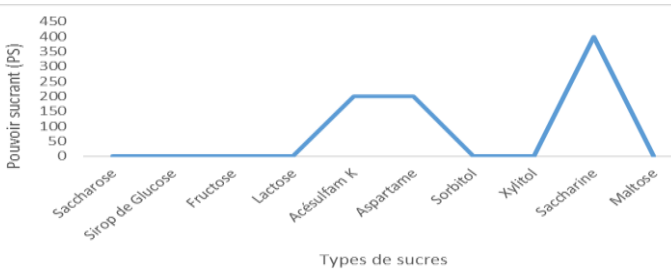

Figure 2: PS curve of some sugars with reference the PS of sucrose ( $\mathrm{PS}=1)$

The most commonly used sugar substitutes to prevent caries disease are sorbitol and xylitol. The latter is often preferred for its sweetness and chemical properties compatible with the food industry $[1,19]$. Sorbitol is contraindicated in children under 03 years of age, as it causes digestive disorders [12,28].

Xylitol can be considered as the ideal sugar for patients with snacking behavior. It is not fermentable by oral bacteria and therefore does not cause a drop in $\mathrm{pH}$. In addition, it promotes the emergence of mutant streptococcal strains that are less adherent to dental surfaces, known as X-T (xylitoresistant) [9-11].

\section{EFFECT OF SUGARS DURING THE ODONTOGENESIS PROCESS:}

Carbohydrates have an energy role. They are the primary source of energy in cellular metabolism by providing glucose.

Excessive intake of disaccharides (sucrose) can lead to metabolic disorders such as phosphate deficiency in the body. The latter influences mineralization of teeth being formed because of the critical quantity of the mineral in cellular metabolism. On the other hand, a lack of carbohydrate intake can lead to glucose production from proteins and fats (neoglucogenesis). These nutrients are then diverted from their primary function, which is the constitution of the body's skeleton. [1]

\section{EFFECT OF SUGARS AFTER DENTAL ERUPTION: CARIOGENICITY OF SUGARS :}

The harmful habit of sweetness is acquired from a rich diet in carbohydrates or sugar in children. It will later result in a high risk of caries. Each food intake contains fermentable carbohydrates, bacteria bound to the tooth surface within the bacterial biofilm use these sugars to produce acids. At a critical $\mathrm{pH}$ of 5.5, the hard tissues of the teeth begin to demineralize. [2] This demineralization is more accelerated in teeth with immature enamel (permeability of the enamel layer, width of the dentinal tubules, ratio of mineral phase to organic phase).

Table 1: sugar content of some frequently consumed foods, the measurement reference is the cube of sugar of gauge 3 or 4.

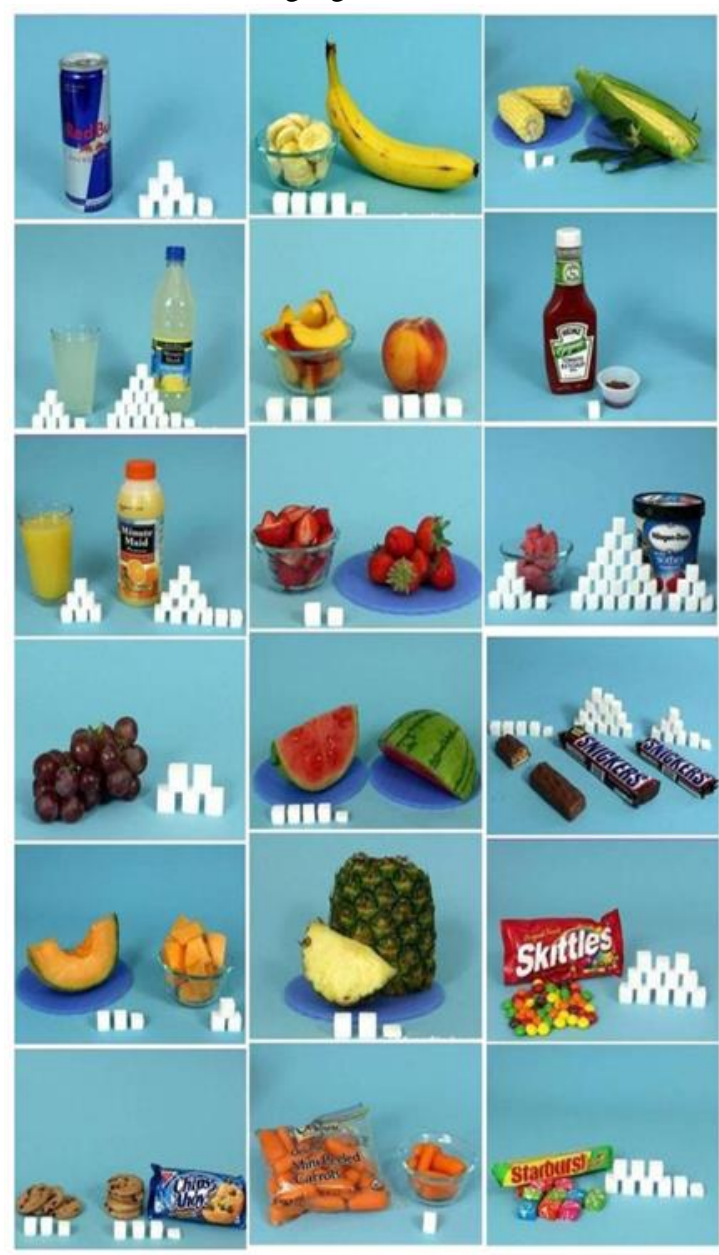

\section{HE DIFFERENT INFLUENCES OF THE} CARIOGENIC POTENTIAL OF SUGARS :

Sucrose is considered the most cariogenic of simple carbohydrates: it is easily fermentable into organic acids (lactic acid) by the biofilm bacteria. It favors the colonization of the oral cavity by streptococcus mutans. It increases the quantity of bacterial biofilm by serving as a substrate for the production of extracellular 
polysaccharides. There is a correlation between the amount of sucrose ingested and the increase in streptococcus mutans within the oral ecosystem. [21,25] Several works show that glucose and fructose are also highly cariogenic. Lactose has the lowest cariogenic potential than sucrose, glucose, and fructose [2] (Figure 3).

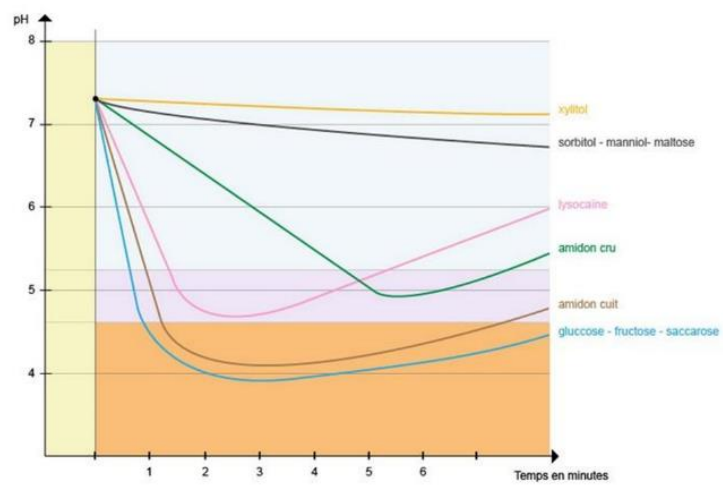

Figure 3: Modified Stéphane curve, showing the variation of $\mathrm{pH}$ with time, under the effect of some carbohydrates and substitute sugars

Fruit carbohydrates have an intense cariogenic action compared to sucrose because they lower the $\mathrm{pH}$ of the biofilm less. [1]. Complex carbohydrates (starch) are more acidogenic than simple carbohydrates (high retentive power and slow degradation). Cooked starch is more cariogenic than raw starch. It should be remembered that all fermentable carbohydrates are cariogenic to varying degrees. [3] . Figure 4 illustrates the demineralizationremineralization process of the tooth as a function of the $\mathrm{pH}$ of the biofilm during sugar consumption. [27] The modified Stephane curve shows the effect of some sugars on oral $\mathrm{pH}$ as a function of time. (Figure 3) [26]. The order of the sugary food in the meal chronology also influences the $\mathrm{pH}$ drop. The consumption of protective food after a cariogenic (sweet) food lead to a decrease in the postprandial acidification of the bacterial biofilm. This rise in $\mathrm{pH}$ is explained by the chemical composition of the protective food, which makes it cariostatic. Taking a cheese at the end of a meal, for example, would reduce the cariogenic effect of the sweet dessert. It would also seem that specific cheese components, such as casein, add to the effect of saliva. By adhering to the dental enamel, they would protect the teeth from acid attacks. [6,7]

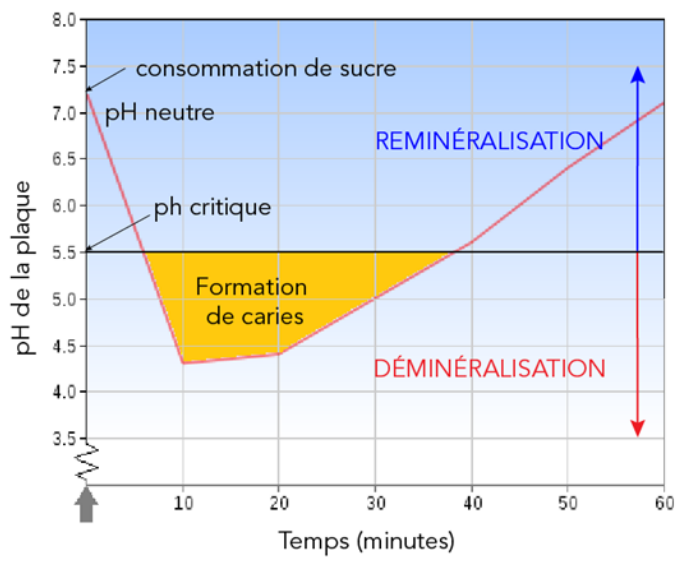

Figure 4: Stéphane's curve, showing the demineralization-remineralization process during sugar consumption.

Cariogenicity of food depends on the sugar used (texture and taste resulting from refinement or not) and the time that this food spends in the oral cavity, Its frequency of intake, and its information during the day. It is, therefore, more accurate to speak of the caries-inducing potential of food than of its cariogenicity. [4]

Salivary flow varies daily (during meals, low between meals, almost nil at night when lying down). Take between meals or at night, and saliva will not be able to play its selfcleansing role [5]. The buffering capacity is then exceeded, resulting in an imbalance between the natural demineralization-remineralization exchanges of the teeth. $[1,2,4]$

Chewing hard food also stimulates salivary secretion, thus speeding up oral evacuation and diluting acids [1], thus reducing the contact time with the teeth $[7,8]$.

Table 2: Some sugars, their PS, their influence on the $\mathrm{pH}$ of the biofilm, and their cariogenic power

\begin{tabular}{llcc}
\hline Types of sugars & $\begin{array}{c}\text { Sweetening power (SP) } \\
\text { Influence on the pH of the bio } \\
\text { film }\end{array}$ & $\begin{array}{c}\text { Cariogenic power according to the frequency } \\
\text { of consumption and other factors }\end{array}$ & $\begin{array}{c}\text { High }+++ \\
\text { High }++\end{array}$ \\
\hline Sucrose & 1 & Low +++ & High + \\
Fructose & $0,75-0,80$ & Low ++ & High + \\
Lactose & $1,1-1,3$ & Low ++ & Nil \\
Acesulfam K & 0,30 & Low + & Nil \\
Aspartame & 200 & Nil & Weak \\
Sorbitol & 200 & Low + & Nil \\
Xylitol & $0,5-0,6$ & Nil & Nil \\
Saccharin & $0,9-1$ & Nil & High ++ \\
Maltose & $300-500$ & Low ++ & \\
\hline
\end{tabular}

\section{DISCUSSION AND RECOMMENDATIONS}

Sugars are the primary source of energy for the cells that ensure the proper functioning of the body, mainly the muscles and the brain.

It is the most used source of energy by the body. It is essential to consume the correct type of sugar, not in excess and at the right time.

Sugars are consumed mainly for the pleasure they bring. The habit of sweet taste can create an addiction, which is difficult to eradicate. $[23,24]$
Observational and intervention data in humans show that sugars are the main dietary factor linked to caries disease. Controlling sugar intake is therefore of paramount importance in the prevention of caries disease. International recommendations for general health discourage snacking and encourage a balanced diet rich in solid foods containing starch, fiber, vitamins, fruits, and vegetables, and low in simple sugars and fats $[13,14,15]$. Therefore, the diet recommended to prevent caries disease is not devoid of sugars or foods with cariogenic potential. 
Still, it encourages a more reasonable behavior towards the consumption of sugars.

The consumption of sugary foods alone does not imply the development of caries. Other host factors are associated with it (the amount of sugar consumed, its consistency, its duration of contact with the teeth, the time, and frequency of its consumption).

A longitudinal study has shown that tooth brushing alone cannot prevent caries disease in children under five. [22]. Therefore, ensuring brushing does not protect against the effects of excessive and frequent sugar consumption.

Although influenced by many biological, behavioral, social, cultural, and environmental factors, sugar remains a significant risk factor for dental caries. Its consumption has an increasing tendency, especially with the current diet. That's why the WHO has proposed a $20 \%$ tax on sugary drinks to reduce their consumption.

For its part, the High Authority of Health (HAS) recommends good eating habits for the prevention of cavities, namely

- reducing the frequency of food intake between meals (snacking including sugary drinks).

- the adoption of a diversified and balanced diet during meals and the consumption of pure water preferably.

After each food or drink intake (except pure water) cannot be followed by brushing the teeth. Keep in mind that

DISCLOSURE: The authors did not receive any funding for the preparation of this case report.

CONFLICTS OF INTEREST: The authors declare that they have no conflicts of interest. xylitol-containing chewing gums are not a substitute for tooth brushing. [13,14,16]

In our opinion, other measures can target the labeling of products rich in sugars and strengthen the education of vulnerable children to develop the habit of sweet taste.

Therefore, to prevent caries disease, it is necessary to pay attention to the sugars consumed, reduce the quantities and frequency of consumption, and have an intelligent consumption of sugar to benefit from their energy intake without harming oral health.

The WHO in 2015 recommended a daily intake of sugars per day to less than three teaspoons (about 12 grams) for young children and less than six teaspoons (about 25 grams) for older children.

In practice, the recommendations to prevent caries can be summarized as follows

- avoid sugary bottles at bedtime for infants,

- Be careful with medicines in the form of sweetened syrups given to children,

- Implementing and maintaining reasonable oral hygiene measures as soon as the first teeth appear,

- replace cariogenic sugars with non-cariogenic sugars whenever possible,

- prefer water to sugary drinks and sodas,

- fight against risky behaviors (snacking).

AUTHORS' CONTRIBUTIONS:

Monique EZIN: Conceptualization, Writing an original draft, \& editing. Houda EL KHAMMAL: Writing, review \& editing. Hakima CHHOUL: Supervision, Validation, \& review. 


\section{REFERENCES}

[1] Galmiche F. Le rôle de l'alimentation dans la santé buccodentaire. Sci Vivant (q-bio). 2011; Hal-01739082. [Accessed 2021 Nov 11]. Available from : https://hal.univ-lorraine.fr/hal-01739082/document

[2] Fioretti F, Haikel Y. Carie et sucres : Caries and Sugars. Méd Malad Métabol. 2010 Oct ; 4(5) : 543-549. Doi: 10.1016/S1957-2557(10)70120-6

[3] Lucile J, Alimentation et Santé dentaire. Chirurgiendentiste de France. 1996 ; N813.

[4] Birkhed D, Nutrition, alimentation et carie dentaire. La Dentisterie Préventive. Montréal: presse Université de Montréal-Masson. 1989; 13:214-46.

[5] Burt BA, Eklund SA, Morgan KJ, Larkin FE, Guire KE, Brown LO, et al. The effects of sugars intake and frequency of ingestion on dental caries increment in a three-year longitudinal study. J Dent Res.1988 Nov; 67 (11): 1422-9. Doi: 10.1177/00220345880670111201

[6] Bowen WH, Amsbaugh SM, Monell-Torrens S, Brunelle J. Effects of varying intervals between meals on dental caries in rats. Caries Res. 1983; 17(5) : 466-71. Doi: $10.1159 / 000260703$

[7] Moynihan PJ. Dietary advice in dental practice. Br Dent J. 2002 Nov 23; 193 (10):563-8. Doi: 10.1038/sj.bdj.4801628

[8] Edgar W. Diet as a determinant of caries risk. In: Johnson NW, editor. Dental caries: risk markers for oral diseas I. Cambridge : Cambridge University press ; 1991:218-51

[9] Machiulskiene V, Nyvad B, Baelum V. Caries preventive effect of sugar-substituted chewing gum. Community Dent Oral Epidemiol. 2001 Aug; 29 (4): 278-88. Doi: 10.1034/j.1600-0528.2001.290407.x

[10] Peldyak J. Mäkinen KK. Xylitol for caries prevention. J Dent Hyg. Fall 2002;76(4) 276-85.

[11] Morrier JJ, Xylitol. Alimentation et prévention de la carie dentaire. J Odonto Stomatol. Pédiatr. 2003 ; 10 (4) : 211220.

[12] Naulin-ifi C. Odontologie pédiatrique. Collection JPIO. $2011 ; 288$.

[13] Agence française de sécurité sanitaire des aliments (Afssa). Glucides et santé : Etat des lieux, évaluation et recommandations. 2004 Oct. [Accessed 2021 Nov 09]. Available from:

https://www.anses.fr/fr/system/files/NUT-RaGlucides.pdf

[14] Moynihan PJ., The rôle of diet and nutrition in the etiology and prevention of oral dieseases Bull World Health Organ. 2005 Sep; 83(9):694-9. [Accessed 2021 Nov 09]. Available from:

https://www.scielosp.org/article/ssm/content/raw/?resourc e ssm path=/media/assets/bwho/v83n9/v83n9a15.pdf

[15] Marinho VC, Higgins JP, Sheiham A, Logan S. Combinaisons of topical fluoride (toothpastes, mouthrineses, gels, varnishes) versus single topical fluoride for preventing dental caries in children and adolescents. Cochrane Database Syst Rév. 2004; 2004(1):CD002781.

Doi: $10.1002 / 14651858 . c d 002781 . p u b 2$

[16] World Dental Fédération (fdi), sucres et caries dentaires, un guide pratique pour réduire la consommation de sucres et enrayer l'épidémie de caries dentaire ; 2017. [Accessed 2021 Nov 09]. Available from: https://www.fdiworlddental.org/sites/default/files/2020 11/sugar toolkit-fdi-2017-fr.pdf

[17] Walker AR, Cleaton-Jones PE. Sugar intake and dental caries: where do we stand? ASDC J Dent Child. Jan-Feb 1989; 56(1) :30-5.

[18] Harel-Raviv M. Caries dentaires et consommation de sucre au $21^{\text {ème }}$ siècle. Suis J Dent. 1996 ; 9(5) :184-90.

[19] Borges Y. Les substituts du sucres dans la prévalence des caries dentaires: Revue de littérature. Pratiquez Odontal.1991; 12(8) :59-60-62-64-5.

[20] Makinen KK., Sugar Alcohol Sweeteners as alternatives to sugar with special consideration of xylitol; Med Princ Pract. $2011 ; 20(4): 303-20$

[21] Newbrun E, Saccharose dans la dynamique du processus carieux, Int Dent J. 1982 ; 32(1) :13-23

[22] Skafida V, Chambers S. Positive association between sugar consumption and dental decay prevalence independent of oral hygiene in pre-school children: a longitudinal prospective study. J Public Health (Oxf). 2018 Sep 1; 40(3): e275- e283. Doi: $10.1093 / \mathrm{pubmed} / \mathrm{fdx} 184$

[23] Masson LF. Apport en sucre et carie dentaire : résultats d'une enquête nationale sur les enfants en Ecosse. Br J Nutr. 2010; 104(10):1555-64.

[24] Yabao RN, Duante CA, Velandria FV, Lucas M, Kassu A, Nakamori M, et al. Prévalence de la carie dentaire et de la consommation de sucre chez les écoliers de 6 à 12 ans à la trinidad. Benget, Philippines. Eur J Clin Nutr. 2005 Dec; 59(12) :1429-38

Doi: $10.1038 /$ sj.ejen. 1602258

[25] Naidoo S. Nutrition, Santé-bucco-dentaire et jeune enfant, Matern Child Nutr. 2007 ; 3(4) : 312-21.

[26] https://images.app.goo.gl/cE2xwXVina8gHA [Accessed 2021 Feb 11]

[27] https://images.app.goo.gl/2iMSJj6Or4Jz4vfB8 [Accessed 2021 Feb 11]

[28] Gunepin M, Derache F. Impact du xylitol sur le risque carieux-implications militaires. Méd Armées. 2010 Jan: 38(4) :369-80. [Accessed 2021 Nov 09]. Available from : http://www.ecole-

valdegrace.sante.defense.gouv.fr/IMG/pdf/31_Gunepin_M-

Impact du Xylitol sur le risque carieux implications_militaires.pdf

[29] https://pin.it/7laj0Y3 [Accessed $2021 \mathrm{Feb} 11]$

[30] https://images.app.goo.gl/r75xF8L7xrq496Xg8 [Accessed 2021 Nov 09] 